Tropical Journal of Pharmaceutical Research September 2021; 20 (9): 1949-1959

ISSN: $1596-5996$ (print); 1596-9827 (electronic) (C) Pharmacotherapy Group, Faculty of Pharmacy, University of Benin, Benin City, 300001 Nigeria.

\title{
A new sensitive HPLC/UV method for simultaneous determination of paclitaxel, sorafenib and omeprazole in standard solutions and spiked plasma: Application to in- vitro and in-vivo evaluation of paclitaxel polymeric nanoformulations
}

\author{
Mirina Sakhi', Abad Khan ${ }^{1 *}$, Ismail Khan1, Zafar Iqbal'², Sumaira Irum Khan², \\ Muzna Ali khattak ${ }^{2}$, Fahim Ullah ${ }^{3}$, Akhtar Aman ${ }^{4}$, Mehboob Alam ${ }^{5}$ \\ ${ }^{1}$ Department of Pharmacy, University of Swabi, Swabi-23561, ${ }^{2}$ Department of Pharmacy, University of Peshawar, ${ }^{3}$ Department \\ of Pharmacy, City University of Science and Information Technology, Peshawar, ${ }^{4}$ Department of Pharmacy, Shaheed Benazir \\ Bhutto University, Sheringal, Upper Dir District, Khyber Pakhtunkhwa, ${ }^{5}$ Department of Pharmacy, Capital University of Science \\ and Information Technology, Islamabad, Pakistan
}

*For correspondence: Email: drabadkhan@uoswabi.edu.pk; Tel: +92 938 490236; Fax: +92 938490238

\begin{abstract}
Purpose: To develop a simple, novel, sensitive and rapid reverse phase high performance liquid chromatographic method for simultaneous determination of paclitaxel, sorafenib and omeprazole in standard solutions and spiked human plasma and its application to the in-vitro and in-vivo evaluation of paclitaxel polymeric nanoparticle formulations.

Methods: The method was tested for the assessment of paclitaxel, omeprazole and sorafenib using tamoxifen citrate as internal standard. The analysis was performed at a wavelength of $235 \mathrm{~nm}$ using Thermo HS C18 column, $40{ }^{\circ} \mathrm{C}$ column oven temperature, acetonitrile and water $(70: 30 \mathrm{v} / \mathrm{v}, \mathrm{pH} 3.37$ adjusted with phosphoric acid) as a mobile phase and at a flow rate of $0.8 \mathrm{ml} / \mathrm{min}$. All analytes were extracted by simple protein precipitation method using acetonitrile. The linearity was assessed in the concentration range of 1 - $2000 \mathrm{ng} / \mathrm{mL}$ for paclitaxel, omeprazole and sorafenib.

Results: The developed chromatographic method effectively separated omeprazole, paclitaxel, sorafenib and IS with retention time of 3.93, 5.18, 6.43 and 9.93 min, respectively. The chromatograms of the three target compounds and IS showed good resolution and peak separation. The LOD of the method was 1, 5 and. $5 \mathrm{ng} / \mathrm{mL}$ while the $L O Q$ was 2, 7.5 and $10 \mathrm{ng} / \mathrm{mL}$, for paclitaxel, sorafenib and omeprazole, respectively.

Conclusion: The proposed RP-HPLC-UV method for the assessment of paclitaxel, sorafenib and omeprazole in standard solutions and spiked plasma is simple, economical, sensitive and robust. The method is also suitable for the analysis of paclitaxel in nanoformulations and for its pharmacokinetic studies in an animal model.
\end{abstract}

Keywords: Paclitaxel, Sorafenib, Omeprazole, Tamoxifen citrate, RP-HPLC, Nanoformulations

This is an Open Access article that uses a funding model which does not charge readers or their institutions for access and distributed under the terms of the Creative Commons Attribution License (http://creativecommons.org/licenses/by/4.0) and the Budapest Open Access Initiative (http://www.budapestopenaccessinitiative.org/read), which permit unrestricted use, distribution, and reproduction in any medium, provided the original work is properly credited.

Tropical Journal of Pharmaceutical Research is indexed by Science Citation Index (SciSearch), Scopus, International Pharmaceutical Abstract, Chemical Abstracts, Embase, Index Copernicus, EBSCO, African Index Medicus, JournalSeek, Journal Citation Reports/Science Edition, Directory of Open Access Journals (DOAJ), African Journal Online, Bioline International, Open-J-Gate and Pharmacy Abstracts 


\section{INTRODUCTION}

Paclitaxel, a di-terpenoid pseudoalkaloid, discovered in 1962 and isolated from pacific yew tree bark, Taxus Brevifolia [1] is a mitotic inhibitor used in cancer chemotherapy [2]. It represents the first generation of the taxanes family of drugs [3]. It is highly lipophilic and formulated with ethanol and cremophor EL (polyoxyethylated castor oil) [4]. Paclitaxel has anti-cancerous properties and is particularly effective in ovarian carcinoma, breast cancer, colon cancer, head cancer, lung cancer, HIVIAIDS related Kaposi's sarcoma [5] and nonsmall lung cancer [3]. A paclitaxel-tubulin complex is formed by its binding to the $\beta$-subunit of tubulin (building block of microtubules) and arresting the ability of tubulin to disassemble, which adversely affects cell function [6]. Furthermore, paclitaxel inhibits metaphase anaphase transition, and binds to B-cell. leukemia 2 (an apoptosis stopping protein), arresting its function by inducing apoptosis [7].

Sorafenib, a small molecule, is an active oral multikinase inhibitor which effectively inhibits tumor angiogenesis, tumor cell proliferation and survival, and is found to induce apoptosis in various tumor models (Advanced Hepatocellular Carcinoma, Advanced Clear-Cell. Renal-Cell Carcinoma). Sorafenib is indicated in advanced renal cells [8], hepatocellular [9] and advanced hepatocellular carcinomas [10]. It has rapid oral absorption, undergoes enterohepatic circulation and has an elimination half-life of 25-48 h [11]. Omeprazole is a substituted benzimidazole sulfoxide used for the treatment of gastric ulcers [12], and acts by blocking the $\mathrm{H}^{+} / \mathrm{K}^{+}$adenosine triphosphate enzyme system of the gastric parietal cell [13]. It has been widely used in the treatment of peptic ulcer, reflex esophagitis and Zollinger-Ellison syndrome [14]. Tamoxifen citrate is an antiestrogenic compound used as IS in the study. Chemical structures of paclitaxel, sorafenib, omeprazole and tamoxifen are given in Figure 1 A-D, respectively.

There are various methods reported for Paclitaxel analysis such as HPLC/UV detector [13,21-30], RP-HPLC/UV detector [15], HPLC/PDA detector [16], LC/MS [17], and HPLC/UV-DAD-detector [18]. Some other methods for analysis like capillary electrophoresis [19], immune assays [20], micellar electrokinetic chromatography [21] and tubulin-based biochemical analysis [22] have also been reported. These methods have various drawbacks, such as lack of sufficient specificity and sensitivity, complicated extraction procedures, large sample volumes and longer run time. Although LC/MS is a sensitive method for the evaluation of taxanes, however it is very expensive [11].

The developed method in this study was found to be more rapid, sensitive, accurate and novel in the sense that it simultaneously determines paclitaxel, omeprazole, sorafenib and tamoxifen [23] in a single run. The method was validated in accordance with the standard guidelines and was successfully used for the measurement of paclitaxel, omeprazole and sorafenib in spiked human plasma [24].

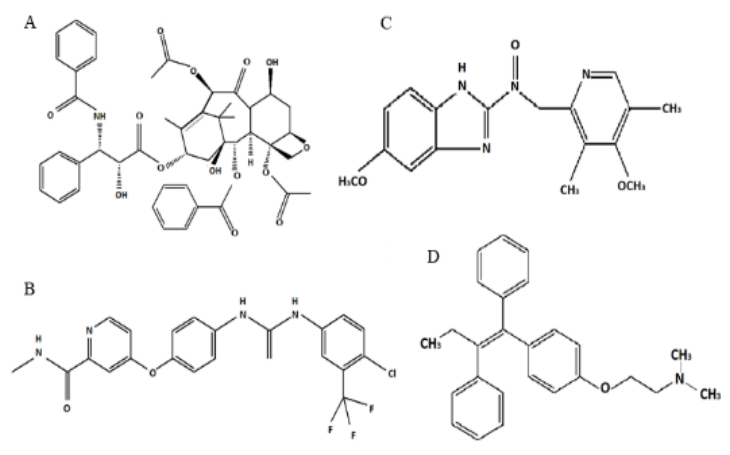

Figure 1: Structures of Paclitaxel (A), Sorafenib (B), Omeprazole (C), Tamoxifen Citrate (D)

\section{EXPERIMENTAL}

\section{Chemicals and reagents}

Paclitaxel ( $\geq 99.9 \%$ purity), Sorafenib ( $\geq 99.9 \%$ purity) and Tamoxifen Citrate ( $\geq 99.9 \%$ purity) were gotten from Qilu Antibiotic Pharmaceutical Co Ltd China. Omeprazole ( $\geq 99.9 \%$ purity) from Ferozsons Laboratories Ltd., PLGA (75:25, Resomer $^{\circledR}$ RG $756 \mathrm{H}$,) from Evonik Germany, PVA, Pluronic ${ }^{\circledR}$ (F-127), and Sodium lauryl sulphate (SLS) from Sigma Aldrich Germany, Disodium Hydrogen Phosphate ( $\left.\mathrm{Na}_{2} \mathrm{HPO}_{4}\right)$, Dialysis Tubing from Sigma-Aldrich Germany, Methanol (purity $\geq 99.9 \%$ ), Acetonitrile (purity $\geq 99.9 \%$ ) and all other chemicals and reagents used were of HPLC grade. Ultra-pure water was used for HPLC solvents preparation.

\section{Equipment}

The study was carried out with the HPLC system (Perkin-Elmer series 200; Norwalk, USA), linked with UV-visible Spectrophotometric detector and Total chrome chromatography work station (version 6.3.1) software with $\mathrm{NCl}$. Separation studies were carried out using Thermo Scientific BDS HS C18 analytical column $(250 \mathrm{~mm} \times 4.6$ $\mathrm{mm}, 5 \mu \mathrm{m})$, and protected with Perkin Elmer precolumn guard cartridge C18 $(30 \mathrm{~mm} \times 4.6 \mathrm{~mm}$, $10 \mu \mathrm{m}$; Norwalk, USA).

Trop J Pharm Res, September 2021; 20(9): 1950 


\section{Chromatographic conditions}

Chromatographic analysis was performed with acetonitrile and 0.01M Phosphate buffer $(\mathrm{pH} 3.37$ adjusted with Phosphoric acid), 70:30 v/v ratio at a flow rate of $0.8 \mathrm{ml} / \mathrm{min}$ in an isocratic mode, at a detector wavelength of $235 \mathrm{~nm}$ and column oven temperature of $40^{\circ} \mathrm{C}$. The sample volume $(50 \mu \mathrm{L})$ was analysed by the HPLC system. The internal standard used for the analytical method was tamoxifen citrate.

\section{Standard solution preparation}

Acetonitrile was used for preparation of analytes and internal standard $(100 \mu \mathrm{g} / \mathrm{mL})$ stock solutions, and stored at-20 ${ }^{\circ} \mathrm{C}$. The stock solution was further diluted with mobile phase to obtain various solutions, with concentrations ranging from 1-500 ng for paclitaxel, 5-1000 ng for sorafenib, 5-1000 ng for omeprazole, while keeping the tamoxifen citrate (I.S) concentration constant i.e., $500 \mathrm{ng} / \mathrm{mL}$.

\section{Blood sample preparation}

Blood was taken in EDTA tubes, and plasma was separated after centrifugation at $8000 \mathrm{rpm}$ for 10 min at $-4{ }^{\circ} \mathrm{C}$. It was then thawed and spiked with paclitaxel, sorafenib, and omeprazole in concentrations of 1-500 ng, 5-1000 ng and 51000 ng, respectively. Samples for HPLC analysis were prepared by protein precipitation method using acetonitrile as a precipitating solvent. Samples were obtained by following the plan outlined in Table1, and was injected (50 $\mu \mathrm{L})$ into the HPLC system.

\section{Rabbit plasma samples}

Both conventional formulations (Paclixil $^{\circledR}, 100$ $\mathrm{mg} / 5 \mathrm{~mL}$, Novartis) and optimized nanoformulations were administered into the marginal ear vein of the rabbits. Blood from rabbits were collected at $0.16,0.5,1,2,4,6,8$, 12, 24, 48, 72, 96 and $120 \mathrm{~h}$ in EDTA tubes and plasma separated using the same procedure as described above.

\section{Extraction procedure}

Extraction of plasma samples was carried out with organic solvents including acetonitrile $(\mathrm{ACN})$, methanol $(\mathrm{MeOH})$ and dichloromethane (DCM). Acetonitrile was chosen for extraction of target analytes and internal standard.

The human blank plasma and rabbit plasma (150 $\mu \mathrm{L})$ were spiked with $10 \mu \mathrm{L}$ (500 ng) each of paclitaxel, sorafenib, omeprazole and internal standard. Three equal parts of $\mathrm{ACN}(450 \mu \mathrm{L})$ were added, vortexed vigorously for $10 \mathrm{mins}$, volume made up with mobile phase, centrifuged at $8000 \mathrm{rpm}$ at $4^{\circ} \mathrm{C}$ for $10 \mathrm{mins}$, and supernatant was collected and injected into the HPLC system for further analysis.

Plasma sample $(150 \mu \mathrm{l})$ Analyte and I.S<smiles></smiles>

$300 \mu \mathrm{l}$ Acetonitrile ( 3 equal parts of plasma)<smiles>[CH]C</smiles>

Vortex for $5 \mathrm{~min}$<smiles>[CH]=C</smiles>

Volume make up with mobile phase<smiles>[CH]=C</smiles>

Centrifugation for $10 \mathrm{mins}$ at $8000 \mathrm{rpm}$ at $4{ }^{\circ} \mathrm{C}$<smiles>[CH]=C</smiles>

Collect the supernatant<smiles></smiles>

Volume make up with mobile phase<smiles>[CH]=C</smiles>

Sample analysis by HPLC

Table 1: Sample preparation scheme

\section{Polymeric nanoparticles preparation and characterization}

Paclitaxel polymeric nanoparticles were prepared using PLGA as a polymer, Pluronic F-127 and Sodium lauryl sulfate (SLS) as a stabilizer utilizing the solvent evaporation method. PLGA concentration was kept constant $(10 \mathrm{mg})$ while Pluronic F-127, SLS and drug were used in varying concentrations. The developed nanoformulations were characterized for its physicochemical properties (size, polydispersity index (PDI), zeta potential), drug loading, \% entrapment efficiency and stability.

\section{Optimization of chromatographic conditions}

The different conditions were optimized. Various RP-HPLC columns including Supelco Discovery HS C18 columns and Thermo HS C18 column were used for separation. Different solvents including methanol, acetonitrile and water using phosphate buffer $\left(\mathrm{KH}_{2} \mathrm{PO}_{4}\right)$ in different compositions were used for optimization of mobile phase composition. Conditions that gave the best results were selected. The experiment was performed using different flow rates in 
isocratic mode ranging from $0.8-1.5 \mathrm{ml} / \mathrm{min}$. For simultaneous quantification of paclitaxel, sorafenib and omeprazole ${ }_{2}$ different wavelengths ranging from 225-245 $\mathrm{nm}$ were evaluated. Various column oven temperatures ranging from $25-35^{\circ} \mathrm{C}$ were studied and the column oven temperature which gave the best result was selected. Various compounds including carbamazepine, Itopride, ondansetron, prednisolone, dexamethasone and tamoxifen citrate were evaluated for the selection of internal standard. The compound showing compatibility and best response was chosen as an internal standard.

\section{Method validation}

The accuracy was confirmed based on the percent recovery method. For determination of $\%$ recoveries of the target drugs at three concentration levels, plasma $(150 \mu \mathrm{L})$ was spiked with different concentrations of each analyte, while keeping the I.S concentration constant. All the samples were injected into the HPLC system in triplicates and \% recovery was calculated using Eq 1.

Recavery $=\frac{(9)}{(2)+18 ?} \times 100$

where

$A=$ Response ratio of drug in the mobile Phase with IS; $B=$ Response ratio of drug in control plasma with IS; $C=$ Response ratio of drug in in spiked plasma with IS

The specificity was evaluated in the mobile phase, blank plasma, 1:1 mixture (containing $1000 \mathrm{ng} / \mathrm{mL}$ each of the analyte and IS) and plasma samples spiked with $1000 \mathrm{ng} / \mathrm{mL}$ each of the studied drugs and IS. Injection repeatability and analysis repeatability was carried out in order to evaluate precision of the developed method. Spiked plasma drug samples and internal standard were injected multiple times (10 times) into the HPLC system for the determination of injection repeatability. The covariance (\%RSD) used as a measure of method precision. The plasma samples (05) spiked $(1000 \mathrm{ng} / \mathrm{mL})$ with each of the target drug and internal standard were analyzed for evaluation of repeatability analysis, prepared individually using same human plasma. For determination of intermediate precision, analysis was performed on spiked plasma samples on the first day (intra-day) and for one week (inter-day) at $08 \mathrm{~h}$ intervals. Concentration was measured as in Eq 2.
$C=\frac{m}{W !} x \frac{G A}{[\sigma]} X F S X E D$

where $X$ and $B$ are peak areas of the analyte and I.S in plasma; $A$ and $Y$ are peak areas of IS and analyte in 1:1 mixture, respectively; $F S=$ analyte concentration in the 1:1 mixture; FD = dilution factor.

Linearity was measured using a least squares regression equation. Both LLOD and LLOQ were determined by using HPLC software ( $\mathrm{S} / \mathrm{N}$ ratio) in order to find out sensitivity of the method. The S/N (Signal to noise) ratio for "LLOD and LLOQ" is 3 and 10 , respectively. Analytes were prepared at concentrations ranging from $1-50 \mathrm{ng} / \mathrm{mL}$ for LOD and LOQ evaluation. The suggested method for ruggedness was assessed by planned variations in chromatographic parameters. Stability studies were carried out for a month on all samples exposed at different storage temperatures $\left(-20,4\right.$ and $\left.25^{\circ} \mathrm{C}\right)$. Stability was determined by analyzing each sample using Eq 3.

$s(\%)=\frac{\text { sip }}{S 0} x 100$

where $\mathrm{St}$ and $\mathrm{S}_{0}$ are drug stability at time, $\mathrm{t}$, and at zero time, respectively.

\section{RESULTS}

By applying this method, all compounds were completely separated within a run time of 10 mins with good instrumental response as shown in Figure 2.

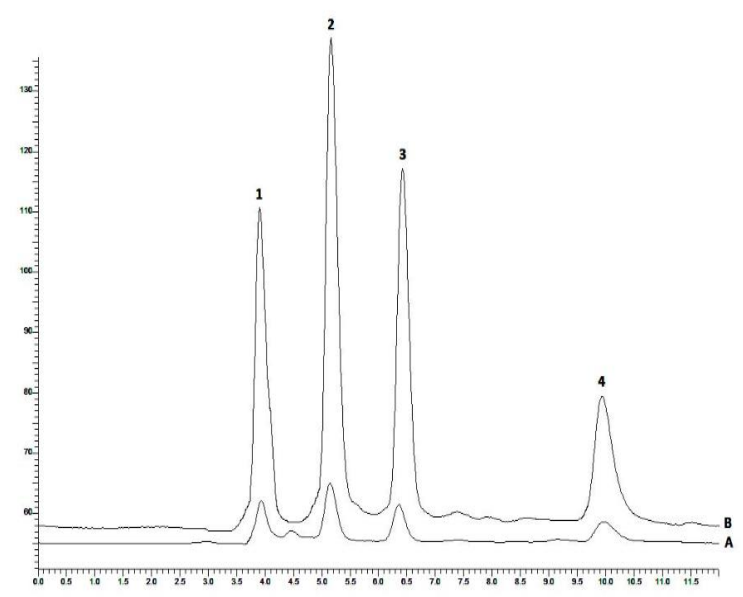

Figure 2: Representative chromatograms. $\mathrm{A}=$ standard solution, $\mathrm{B}=$ spiked plasma samples. Peaks: 1, omeprazole; 2, paclitaxel; 3, sorafenib; 4, tamoxifen. Peak 1, 2, 3 and 4 are omeprazole, paclitaxel, sorafenib and tamoxifen respectively. Mobile Phase= ACN: $\mathrm{H}_{2} \mathrm{O}$, Flow Rate $=0.8 \mathrm{~mL} / \mathrm{min}$, Wavelength $=235$ 


\section{Optimized parameters}

Various experimental conditions were optimized to choose the parameters that show best results. Various analytical columns were assessed for analytes separation. Thermo HS C18 column $(250 \mathrm{~mm} \times 4.6 \mathrm{~mm} \times 5 \mu \mathrm{m})$ was selected since it gave a better peak shape, peak area, best resolution, and separation. Various solvents were tested as mobile phase for the analytical study of target compounds. Acetonitrile and water using phosphate buffer $\left(\mathrm{KH}_{2} \mathrm{PO}_{4}\right)$ with $\mathrm{pH}$ adjusted to 3.37 with phosphoric acid (70:30) were selected for analysis because it gave good resolution, peak shape and reduced elution time as shown in Figure 3.

The effect of different flow rates in isocratic mode was performed, ranging from $0.8-1.5 \mathrm{ml} / \mathrm{min}$. A flow rate of $0.8 \mathrm{ml} / \mathrm{min}$ was selected as it gives better sensitivity and optimum retention time as shown in Figure 4. For simultaneous quantification of paclitaxel, sorafenib, tamoxifen and omeprazole various wavelengths were assessed, ranging from 225 to $245 \mathrm{~nm}$. Better results in terms of sensitivity were achieved at $235 \mathrm{~nm}$ for all the compounds, and it was chosen as the wavelength of detection as shown in Figure 5.

The effect of change in the temperatures from $25-45^{\circ} \mathrm{C}$ was also studied. At $40^{\circ} \mathrm{C}$, shape and height of the peak was found to be improved as shown in Figure 6. Different compounds including carbamazepine, itopride, ondansetron, prednisolone, dexamethasone, and tamoxifen citrate were evaluated. Tamoxifen citrate showed more compatibility.

\section{Prepared sample}

Acetonitrile was chosen to prepare standard stock solutions of paclitaxel, sorafenib, tamoxifen citrate and omeprazole, and their extraction from the spiked and rabbit plasma samples. From the stock solutions, dilutions were made in the mobile phase daily. ACN exhibited better \% recovery and was ideal for protein precipitation when compared with methanol, dichloromethane and other organic solvents.

\section{Method validation results}

Linearity in standard solution and spiked plasma was tested by constructing calibration curves of the analytes $(15-1000 \mathrm{ng} / \mathrm{mL})$ for paclitaxel, omeprazole and sorafenib as presented in Figure 7. The correlation co-efficient ( $r$ ) and the regression equation were linear, as shown in Table 2. The accuracy was evaluated based on percentage recovery at three $(250,500$ and 1000 ng) concentrations of all the target drugs as presented in Table 2. The precision was evaluated by injection repeatability and analysis repeatability, intra-day and inter-day precision studies and the results obtained were found to be in complete harmony as shown in Table 4. In addition, the chromatograms of the three target compounds and I.S showed good resolution and peak separation as presented in Figure 3. The resulting chromatograms confirmed peak separation of target compounds in the mobile phase and spiked plasma samples showing the suitability of the method.

The LOD and LOD values are presented in Table 3. In comparison with previously reported methods, the proposed method is found to be more sensitive $[11,25,26]$. Small deliberate and intentional changes made showed no significant change on elution time, peak characteristics and $\%$ recoveries of the analytes, thus proving the robustness of the method. Stability studies of samples at different storage temperatures (-20, 4 and $25^{\circ} \mathrm{C}$ ) indicated the stability of both samples for $72 \mathrm{~h}$ as shown in Table 5 . The standard solutions were stable at low temperatures (-20 ${ }^{\circ} \mathrm{C}$ ) for one month while the spiked samples showed poor stability and recoveries.

\section{Method applicability}

This method is the part of paclitaxel nanoformulations development and evaluation. It involves nanoformulation preparation, characterization, in-vitro release studies and pharmacokinetic studies of paclitaxel in animals. The suggested method can be used for the simultaneous quantification of paclitaxel, omeprazole and sorafenib in standard solutions and human plasma.

\section{Formulation characterization of paclitaxel}

The nanoformulations of paclitaxel were evaluated based on their particle size, poly dispersity index, zeta potential and entrapment efficiency. Two (PTX 84, PTX 86) out of sixteen nanoformulations were selected on the basis of their physicochemical properties and stability data as shown in Table 6 and Figure 8. These two formulations showed the required characteristics of targeting breast cancer cells, and were further analyzed for in-vitro release profile to identify the mechanism and duration of release. The in-vivo studies were also carried out for the evaluation of various pharmacokinetic parameters. 


\section{In-vitro release}

Dialysis bag diffusion method was used to determine the in-vitro characteristic profile of paclitaxel formulations as shown in figure 9. Dialysis bags carrying $1 \mathrm{ml}$ of nanoformulations and $1 \mathrm{ml}$ of PBS buffer ( $\mathrm{pH}$ adjusted to 7.2) were dialyzed against $100 \mathrm{ml}$ of PBS $\left(37^{\circ} \mathrm{C}\right.$ at $\left.60 \mathrm{rpm}\right)$. At specified time intervals $(0.5,1,2,4,6,8,10$, 12, 24, 36, 48, 72, 96, 120, 144, 168, 192, 216 , 240 and 264 h) $2 \mathrm{~mL}$ sample was withdrawn and analyzed for drug release, usually in triplicate. After each sampling procedure, the dissolution media volume was corrected with same volume.

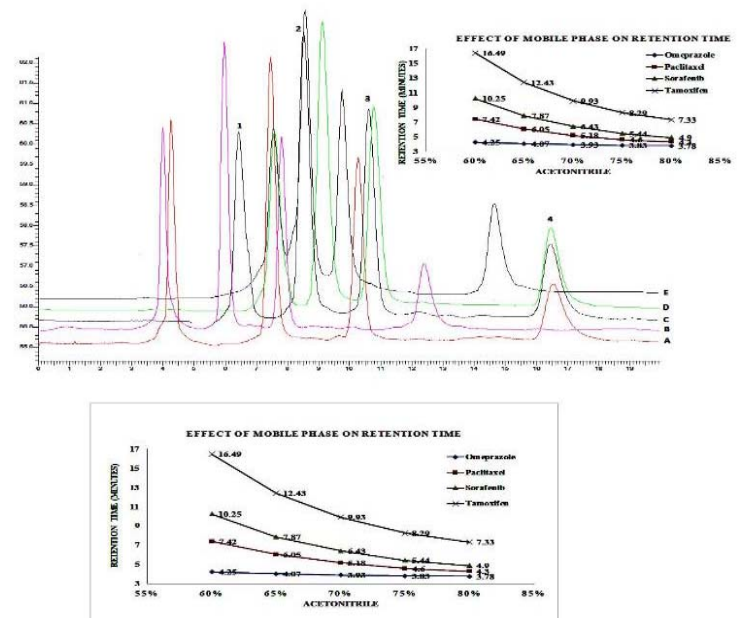

Figure 3: Effect of Acetonitrile (\%) on the elution of analytes. $A=60 \%, B=65 \%, C=70 \%, D=75 \%, E=80$ $\%$, Peak 1, 2, 3 and 4 are omeprazole, paclitaxel, sorafenib and tamoxifen respectively. Mobile phase = ACN: $\mathrm{H}_{2} \mathrm{O}$, flow rate $=0.8 \mathrm{~mL} / \mathrm{min}$, wavelength $=235$ $\mathrm{nm}$
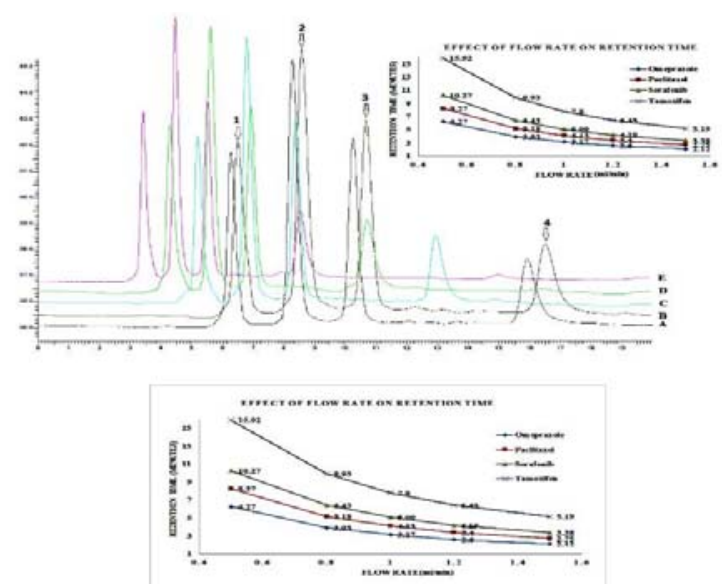

Figure 4: Impact of flow on the elusion of analytes. $A=$ 0.5: $B=0.8: C=1: D=1.2:$ and $E=1.5 \mathrm{~mL} / \mathrm{min}:$ Peak $1,2,3$ and 4 are omeprazole, paclitaxel, sorafenib and tamoxifen respectively. Mobile Phase $=A C N$ : $\mathrm{H}_{2} \mathrm{O}$, Flow Rate $=0.8 \mathrm{~mL} / \mathrm{min}$, Wavelength $=235 \mathrm{~nm}$
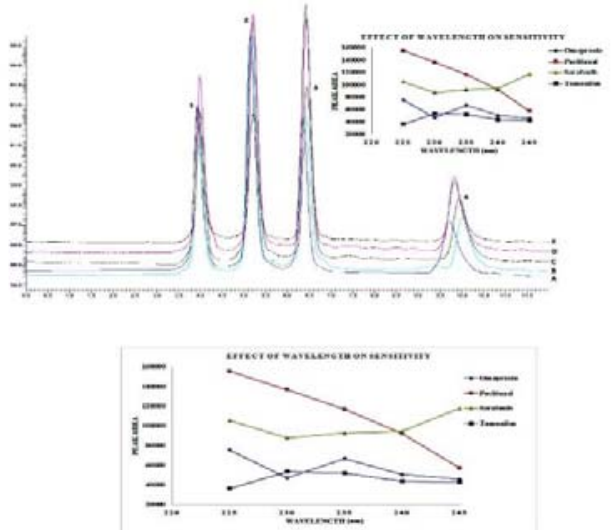

Figure 5: Effect of different detector wavelength on analytes retention times. $A=225 \mathrm{~nm}, B=230 \mathrm{~nm}, C=$ $235 \mathrm{~nm}, \mathrm{D}=240 \mathrm{~nm}, \mathrm{E}=245 \mathrm{~nm}$. Peak 1, 2, 3 and 4 are omeprazole, paclitaxel, sorafenib and tamoxifen respectively. Mobile phase $=\mathrm{ACN}: \mathrm{H}_{2} \mathrm{O}$, flow rate $=0.8$ $\mathrm{mL} / \mathrm{min}$

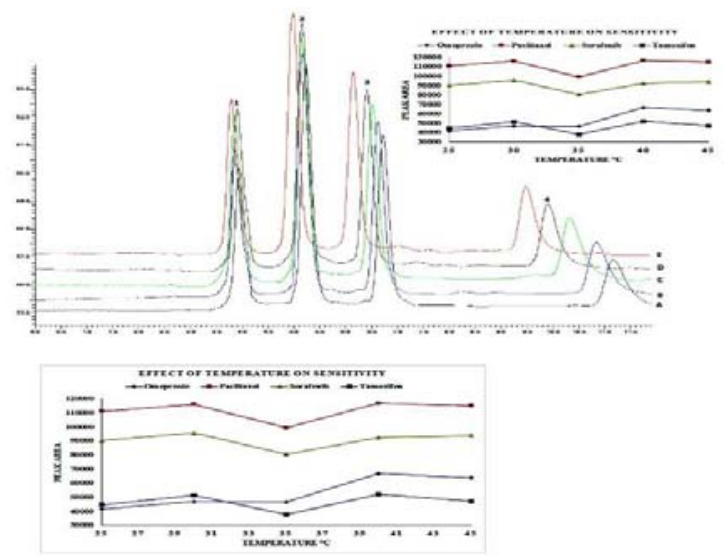

Figure 6: Effect of different column oven temperature. $\mathrm{A}=25^{\circ} \mathrm{C} \mathrm{B}=30^{\circ} \mathrm{C}=35^{\circ} \mathrm{C} \mathrm{D}=40^{\circ} \mathrm{C} \mathrm{E}=45^{\circ} \mathrm{C}$. E, Peak 1, 2, 3 and 4 are omeprazole, paclitaxel, sorafenib and tamoxifen respectively. Mobile phase $=$ ACN: $\mathrm{H}_{2} \mathrm{O}$, flow rate $=0.8 \mathrm{~mL} / \mathrm{min}$, wavelength $=$ $235 \mathrm{~nm}$
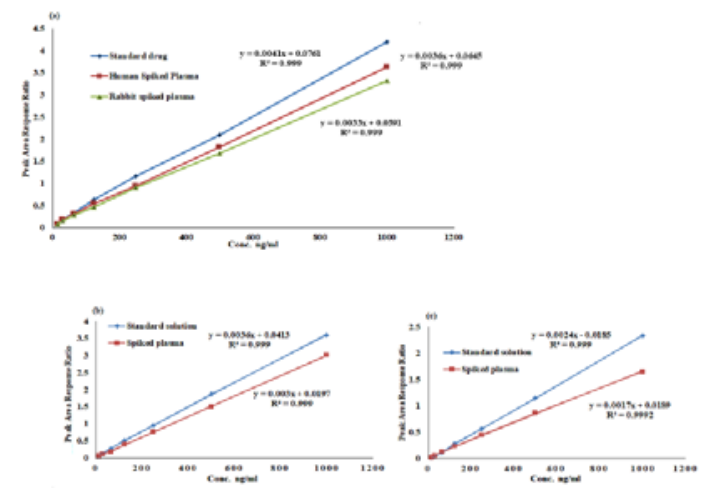

Figure 7: Linearity of (a) paclitaxel (b) sorafenib and (c) omeprazole in spiked plasma and standard solution 
Table 2: Linearity and accuracy of the method

\begin{tabular}{|c|c|c|c|}
\hline Parameter & Paclitaxel (mean \pm SD; \% RSD) & $\begin{array}{c}\text { Sorafenib (mean } \pm \text { SD; \% } \\
\text { RSD) }\end{array}$ & $\begin{array}{c}\text { Omeprazole (mean } \pm \text { SD; } \\
\% \text { RSD) }\end{array}$ \\
\hline \multicolumn{4}{|l|}{ Standard mixture } \\
\hline Correlation coefficient $\left(R^{2}\right)$ & 0.9952 & 0.9979 & 0.9994 \\
\hline \multicolumn{4}{|c|}{ Spiked Human plasma samples } \\
\hline Regression equation & $y=0.0033 x-0.1627$ & $y=0.003 x-0.757$ & $y=0.0017 x-0.523$ \\
\hline Correlation coefficient $\left(\mathrm{R}^{2}\right)$ & 0.9906 & 0.9983 & 0.9906 \\
\hline Correlation coefficient $\left(\mathrm{R}^{2}\right)$ & 0.9917 & - & - \\
\hline \multicolumn{4}{|l|}{${ }^{*}$ Accuracy (\% recovery) $\mu \mathrm{g} / \mathrm{ml}$} \\
\hline 0.25 & $88.46 \pm 0.38 ; 0.43$ & $81.83 \pm 0.48 ; 0.59$ & $81.27 \pm 0.13 ; 0.16$ \\
\hline 0.5 & $80.76 \pm 0.39 ; 0.48$ & $76.47 \pm 0.097 ; 0.13$ & $82.91 \pm 0.55 ; 0.67$ \\
\hline 1.0 & $81.42 \pm 0.43 ; 0.53$ & $79.42 \pm 0.42 ; 0.52$ & $70.73 \pm 0.38 ; 0.54$ \\
\hline \multicolumn{4}{|c|}{${ }^{*}$ Accuracy (amount recovered) $\mu \mathrm{g} / \mathrm{ml}$} \\
\hline 0.25 & $98.5 \pm 0.51 ; 0.51$ & - & - \\
\hline 0.5 & $83.52 \pm 0.14 ; 0.17$ & - & - \\
\hline 1.0 & $83.97 \pm 0.38 ; 0.45$ & - & - \\
\hline \multicolumn{4}{|c|}{${ }^{\star *}$ Accuracy (amount recovered) $(\mu \mathrm{g} / \mathrm{ml})$} \\
\hline 0.25 & $0.23 \pm 0.005 ; 2.21$ & - & - \\
\hline 0.5 & $0.43 \pm 0.009 ; 2.28$ & - & - \\
\hline 1.0 & $0.95 \pm 0.005 ; 0.52$ & - & - \\
\hline
\end{tabular}

"Spiked human plasma; ${ }^{* *}$ spiked rabbit plasma

Table 3: Repeatability and sensitivity of the method

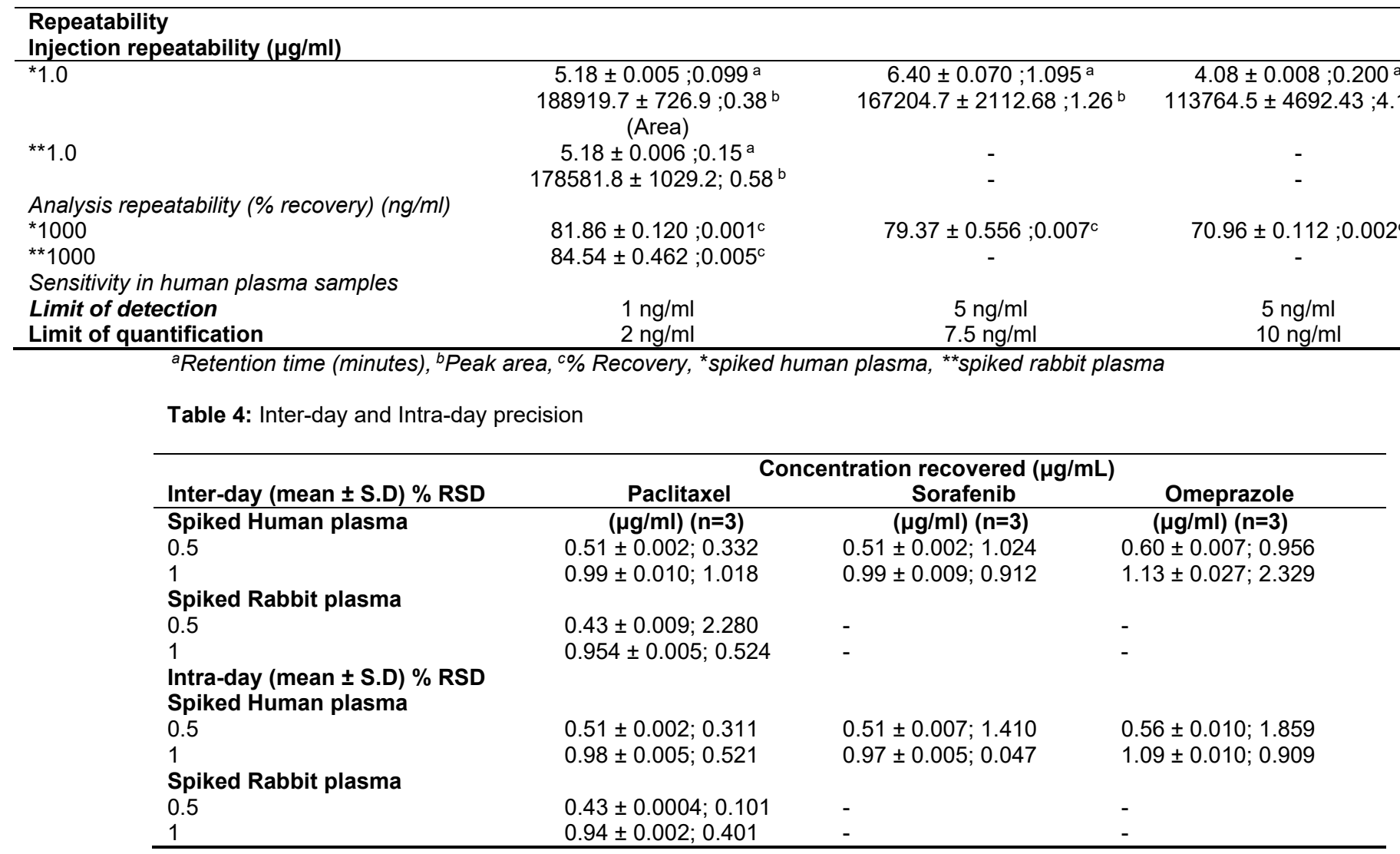


Table 5: Paclitaxel stability in plasma

\begin{tabular}{llccc}
\hline $\begin{array}{l}\text { Plasma Storage } \\
\text { condition }\end{array}$ & $\begin{array}{l}\text { Storage } \\
\text { (hours) }\end{array}$ & Time & \multicolumn{2}{c}{$\begin{array}{l}\text { (\% Recovery } \mathbf{\pm ~ S D ; ~ \% ~ R S D ) ~} \\
\mathbf{5 0 0} \mathbf{~ n g} / \mathbf{m L}\end{array}$} \\
\hline $25{ }^{\circ} \mathrm{C}$ & 0 & $88.46 \pm 0.39 ; 0.43$ & $80.37 \pm 0.38 ; 0.48$ & $\mathbf{1 0 0 0} \mathbf{~ n g} / \mathbf{m L}$ \\
& 6 & $88.45 \pm 0.41 ; 0.45$ & $79.58 \pm 0.43 ; 0.24$ & $81.99 \pm 0.43 ; 0.53$ \\
& 24 & $90.03 \pm 0.51 ; 0.54$ & $82.18 \pm 0.52 ; 0.22$ & $80.76 \pm 0.39 ; 0.48$ \\
& 72 & $89.26 \pm 0.45 ; 0.44$ & $80.25 \pm 0.44 ; 0.27$ & $82.78 \pm 0.43 ; 0.91$ \\
$4{ }^{\circ} \mathrm{C}$ & 6 & $88.31 \pm 0.54 ; 0.65$ & $80.15 \pm 0.52 ; 0.26$ & $81.80 \pm 0.19 ; 0.47$ \\
& 24 & $88.47 \pm 0.58 ; 0.64$ & $80.90 \pm 0.42 ; 0.33$ & $80.69 \pm 0.56 ; 0.50$ \\
Freeze and Thaw 3x & 72 & $88.49 \pm 0.50 ; 0.69$ & $80.03 \pm 0.53 ; 0.46$ & $80.09 \pm 0.42 ; 0.48$ \\
\hline
\end{tabular}

$N=3$ while at " 0 " time, $N=6$

Table 6: Physiochemical characterization of nanoformulations

\begin{tabular}{|c|c|c|c|c|c|c|c|c|}
\hline NO. & $\begin{array}{l}\text { Drug } \\
\text { (mg) }\end{array}$ & $\begin{array}{l}\text { PLGA } \\
\text { (mg) }\end{array}$ & $\begin{array}{l}\text { Stabilizer } \\
\text { (Pluronic } \\
\text { F-127) (\%) }\end{array}$ & $\begin{array}{l}\text { Stabilizer } \\
\text { (SLS) (\%) }\end{array}$ & Size (nm) & $\begin{array}{c}\text { Polydispersit } \\
y\end{array}$ & $\begin{array}{c}\text { Zeta } \\
\text { Potential } \\
(\mathrm{mv})\end{array}$ & $\begin{array}{l}\text { Encapsulation } \\
\text { Efficiency (\%) }\end{array}$ \\
\hline PTX 84 & 1 & 10 & 0.5 & 0.05 & $190 \pm 12.42$ & $0.13 \pm 0.02$ & $-30 \pm 1.1$ & 95 \\
\hline PTX 85 & 2 & 10 & 0.5 & 0.05 & $265 \pm 3.38$ & $0.5 \pm 0.03$ & $-30.9 \pm 0.8$ & 55 \\
\hline PTX 87 & 4 & 10 & 0.5 & 0.05 & $373 \pm 14.47$ & $0.9 \pm 0.08$ & $-38.5 \pm 1.9$ & 63 \\
\hline PTX 88 & 1 & 10 & 1 & 0.05 & $371 \pm 22.61$ & $0.7 \pm 0.02$ & $-29.77 \pm 0.2$ & 96 \\
\hline РТX 89 & 2 & 10 & 1 & 0.05 & $380 \pm 38.97$ & $0.6 \pm 0.04$ & $-24.2 \pm 0.18$ & 61 \\
\hline PTX 92 & 1 & 10 & 1.5 & 0.05 & $261 \pm 11.8$ & $0.4 \pm 0.03$ & $-24.05 \pm 0.9$ & 47 \\
\hline РТX 93 & 2 & 10 & 1.5 & 0.05 & $385 \pm 33.4$ & $1.0 \pm 0.04$ & $-30.59 \pm 0.11$ & 98 \\
\hline РTX 94 & 3 & 10 & 1.5 & 0.05 & $458 \pm 18.5$ & $0.5 \pm 0.04$ & $-31 \pm 0.25$ & 45 \\
\hline РTX 95 & 4 & 10 & 1.5 & 0.05 & $431 \pm 23.9$ & $0.19 \pm 0.01$ & $-33.62 \pm 1.7$ & 50 \\
\hline РTX 96 & 1 & 10 & 2 & 0.05 & $226 \pm 34.37$ & $0.5 \pm 0.02$ & $-28.28 \pm 1.2$ & 44 \\
\hline PTX 97 & 2 & 10 & 2 & 0.05 & $243 \pm 10.04$ & $0.1 \pm 0.02$ & $-29.89 \pm 0.9$ & 19 \\
\hline
\end{tabular}

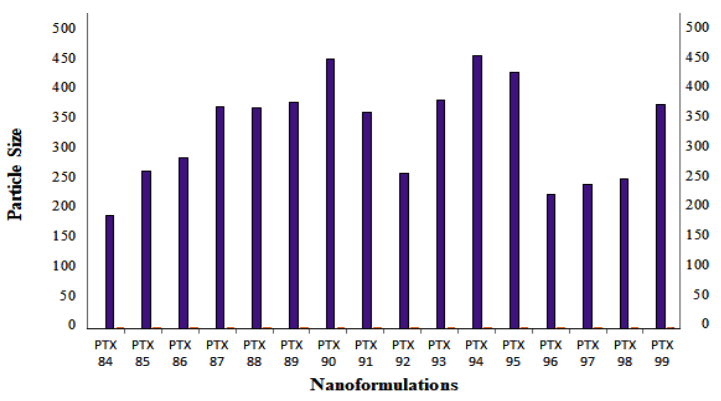

Figure 8: Nanoformulations prepared with PLGA and pluronic F-127 + sodium lauryl sulphate

Mathematical drug release models were used to find out the release mechanism and kinetics of the drug from dosage form. Table 7 shows the regression coefficient values $\left(R^{2}\right)$ obtained from these mathematical models. It was observed that drug release from PTX-84 and PTX-86 formulations best fits the Higuchi model based on higher regression.co-efficient $\left(R^{2}\right)$ values. The " $n$ " value primarily shows the mechanism of drug release from the polymeric materials. The most common release mechanism followed by these formulations is diffusion, followed by erosion. The $n$ value also showed that Fickian diffusion has taken place in the optimized formulations.

\section{In-vivo pharmacokinetics}

Rabbits were used as an experimental model for the assessment of the various in-vivo pharmacokinetic parameters of the paclitaxel nano-formulations.

Table 7: In-vitro release of the optimized nanoformulations

\begin{tabular}{lcccccc}
\hline & 1st Order & $\mathbf{0}$ Order & Higuchi & Hixon Crowell & \multicolumn{2}{c}{ Korsemyer Pappas } \\
Formulation & $\mathbf{R}^{\mathbf{2}}$ & $\mathbf{R}^{\mathbf{2}}$ & $\mathbf{R}^{\mathbf{2}}$ & $\mathbf{R}^{\mathbf{2}}$ & $\mathbf{R}^{\mathbf{2}}$ & $\mathbf{n}^{*}$ \\
\hline PTX 84 & 0.7726 & 0.9857 & $\mathbf{0 . 9 9 6 2}$ & 0.9951 & 0.9946 & 0.5 \\
PTX 86 & 0.881 & 0.9906 & $\mathbf{0 . 9 9 6 3}$ & 0.9953 & 0.9951 & 0.4 \\
\hline
\end{tabular}


Table 8: Pharmacokinetic parameters of paclitaxel

\begin{tabular}{lcccc}
\hline $\begin{array}{l}\text { Pharmacokinetic parameter } \\
\text { (mean } \pm \text { SD) }\end{array}$ & & $\begin{array}{c}\text { Control } \\
\text { (mean } \pm \text { SD) }\end{array}$ & \multicolumn{2}{c}{ Nano-Formulation (mean \pm SD) } \\
PTX 84 & PTX 86 \\
\hline$\left(\mathbf{C}_{\max }\right)$ & $\mu \mathrm{g}$ & $3.50 \pm 0.10$ & $3.61 \pm 0.20$ & $3.65 \pm 0.20$ \\
$\left(\mathbf{T}_{\max }\right)$ & $\mathrm{h}$ & $1.5-2.2 \pm 0.00$ & $2.4 \pm 0.00$ & $2.6 \pm 0.00$ \\
$\left(\mathbf{T}_{1 / 2}\right)_{\text {Elimination Half-life }}$ & $\mathrm{h}$ & $46.90 \pm 3.32$ & $160.93 \pm 4.42$ & $148.21 \pm 3.98$ \\
AUC(0-t) (obs area) & $\mu \mathrm{g}-\mathrm{h} / \mathrm{L}$ & $23628.3 \pm 112.3$ & $537622.2 \pm 1342$ & $673546.9 \pm 1232$ \\
AUMC¥ (area) & $\mu \mathrm{g}-\mathrm{h}^{\star} \mathrm{h} / \mathrm{L}$ & $70.0 \pm 3.10$ & $1851.0 \pm 6.43$ & $1814.0 \pm 5.89$ \\
MRT (area) & $\mathrm{h}$ & $45.4 \pm 1.50$ & $184.4 \pm 2.56$ & $182.8 \pm 2.76$ \\
$(\mathbf{V d})_{\text {(obs area) }}$ & $\mathrm{L}$ & $0.20 \pm 0.01$ & $1.30 \pm 0.23$ & $1.50 \pm 0.12$ \\
$(\mathbf{C L})_{\text {(obs area) }}$ & $\mathrm{L} / \mathrm{hr}$ & $0.64 \pm 0.00$ & $0.006 \pm 0.00$ & $0.002 \pm 0.00$ \\
\hline
\end{tabular}

Various pharmacokinetic parameters (Table 8)

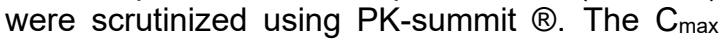
for conventional and nanoparticle formulations (3.50-3.65 $\mathrm{\mu g}$ and $2.20-2.60 \mathrm{~h}$ ) remained the same, with increase in elimination half-life (46.9$160.9 \mathrm{~h}$ ), significant increases in area under the curve (23628-673546 $\mu \mathrm{g}-\mathrm{h} / \mathrm{L})$, area under the movement curve (70.0-1851.0 $\left.\mu \mathrm{g}-\mathrm{h}^{*} \mathrm{~h} / \mathrm{L}\right)$, mean residence time (45.4-184.4 h), volume of distribution (0.20-1.50 L), and a decrease in clearance (0.64-0.002 L/h).
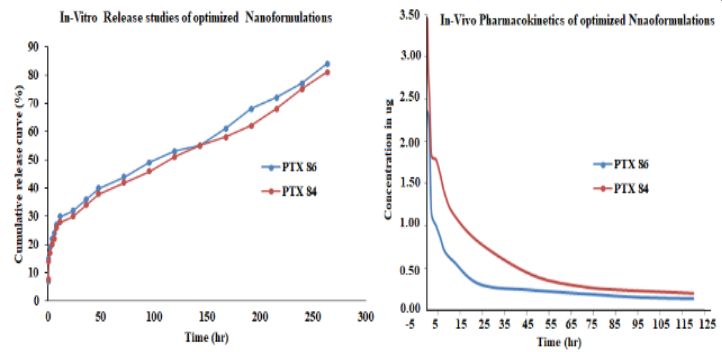

Figure 9: Release profile of paclitaxel nanoformulations

\section{DISCUSSION}

The proposed method is novel and sensitive as for the first time, paclitaxel, sorafenib and omeprazole were quantified in a single chromatographic run using tamoxifen as an internal standard. All compounds were completely separated at a short run time of 10 mins with good instrumental response. Various chromatographic parameters were optimized and selected on the basis of good results. The optimized mobile phase used was acetonitrile and water using phosphate buffer $\left(\mathrm{KH}_{2} \mathrm{PO}_{4}\right)$, with $\mathrm{pH}$ adjusted to 3.37 with phosphoric acid (70:30). Column oven temperature was $40^{\circ} \mathrm{C}$, wavelength $235 \mathrm{~nm}$, and flow rate of mobile phase in isocratic mode was $0.8 \mathrm{ml} / \mathrm{min}$.

The linearity was in the concentration range of 1 $2000 \mathrm{ng} / \mathrm{ml}$. LLOD and LLOQ were $1 \mathrm{ng} / \mathrm{ml}$ and 2 $\mathrm{ng} / \mathrm{ml}$, respectively, which shows that the method is highly sensitive.
The release data showed that it follows Higuchi model, and is Fickian. Various pharmacokinetic parameters such as Cmax, $A \cup C_{0-t}, M R T, t_{1 / 2}, V_{d}$ have shown a significant increase, while clearance of polymeric loaded paclitaxel nanoparticles has decreased than commercially available paclitaxel drug, showing that both formulations follow sustained release.

\section{CONCLUSION}

The reported method has been successfully validated as per standard guidelines. Various chromatographic parameters and experimental conditions have been optimized. The suggested method is applicable for the simultaneous determination of paclitaxel, sorafenib, and omeprazole in solutions and spiked plasma samples. The method is also suitable for the quantification of paclitaxel in nanoformulations and for its pharmacokinetic studies in animals. The method is novel, simple, specific and sensitive for the simultaneous determination of paclitaxel, sorafenib and omeprazole in a single run.

\section{DECLARATIONS}

\section{Acknowledgement}

We are grateful to the Higher Education Commission (HEC) of Pakistan for the financial support. We are also grateful to the University of Peshawar for making available the laboratory facilities for carrying out the work.

\section{Conflict of interest}

No conflict of interest is associated with this work.

\section{Contributions of authors}

We declare that this work was done by the author(s) named in the article and all liability pertaining to claims related to the content of the article will be borne by the authors. Abad Khan is 
the corresponding author who supervised the research work and manuscript writing. Mirina Sakhi carried out the experimental work and manuscript writing. Zafar Iqbal and Ismail Khan helped in designing the project. Sumaira Irum Khan, Muzna Ali Khattak and Fahim Ullah played a role in nanoformulation preparation, characterization, in-vitro and in-vivo studies. Akhtar Aman, Mehboob Alam, Ismail Khan and Abad Khan helped in data analysis and manuscript writing. All authors read and approved the final manuscript for publication.

\section{Open Access}

This is an Open Access article that uses a funding model which does not charge readers or their institutions for access and distributed under the terms of the Creative Commons Attribution License (http://creativecommons.org/licenses/by/ 4.0) and the Budapest Open Access Initiative (http://www.budapestopenaccessinitiative.org/rea d), which permit unrestricted use, distribution, and reproduction in any medium, provided the original work is properly credited.

\section{REFERENCES}

1. Sharma N, Madan P, Lin S. Effect of process and formulation variables on the preparation of parenteral paclitaxel-loaded biodegradable polymeric nanoparticles A co-surfactant study. Asian J Pharmaceut Sci 2016; 11(3): 404-416.

2. WIN KY. Paclitaxel loaded nanoparticles of biodegradable polymers for cancer chemotherapy 2006; (Ph.D Thesis), University of Singapore, Singapore.

3. Wei Y. Pharmacokinetic and tissue distribution of paclitaxel in rabbits assayed by LC-UV after intravenous administration of its novel liposomal formulation. Biomedical Chromatography 2014; 28(2): 204-212.

4. Mortier KA. Development and validation of a liquid Chromatography Tandem mass spectrometry assay for the quantification of docetaxel and paclitaxel in human plasma and oral fluid. Analytical Chem 2005; 77(14): 4677-4683.

5. Averineni RK. PLGA 50: 50 nanoparticles of paclitaxel development, in vitro anti-tumor activity in BT-549 cells and in vivo evaluation. Bulletin of Materials Science 2012; 35(3): 319-326.

6. Greish K. Enhanced permeability and retention of macromolecular drugs in solid tumors, a royal gate for targeted anticancer nanomedicines. Journal of drug targeting 2007; 15(7-8): 457-464.

7. Lopez LZ. Determination of docetaxel and paclitaxel in human plasma by high-performance liquid chromatography validation and application to clinical pharmacokinetic studies. Therapeut Drug Monitoring 2006; 28(2): 199-205.
8. Wilhelm S. Discovery and development of sorafenib: a multikinase inhibitor for treating cancer. Nature reviews Drug discovery 2006; 5(10): 835-844.

9. Kim R. What is the indication for sorafenib in hepatocellular carcinoma? A clinical challenge. Oncology 2011; 25(3): 283.

10. Connock M. Sorafenib for the treatment of advanced hepatocellular carcinoma. Health Technol Assess 2010; 14(Supp/ 1): 17-21.

11. Khan I. A simple, rapid and sensitive RP-HPLC-UV method for the simultaneous determination of sorafenib \& paclitaxel in plasma and pharmaceutical dosage forms Application to pharmacokinetic study. Journal of Chromatography B 2016; 1033: 261-270.

12. Sluggett GW. Omeprazole determination using HPLC with coulometric detection. Journal of pharmaceutical and biomedical analysis 2001; 25(3): 357-361.

13. El-Sherif ZA. Reversed-phase high performance liquid chromatographic method for the determination of lansoprazole, omeprazole and pantoprazole sodium sesquihydrate in presence of their Acid-induced degradation products. Chemical and pharmaceutical bulletin 2006; 54(6): 814-818.

14. Kang WK, Kim DS, Kwon KI. Advanced method for determination of omeprazole in plasma by HPLC. Archives of pharmacal research 1999; 22(1): 86-88.

15. Haruo Y, Mihoko N, WadaMitsuhiro NKI. The estimation of paclitaxel in Parenterals by RP-HPLC. Asian J. Research Chem 2009; 2(1): 90-92

16. Badea I. Rapid HPLC method for the determination of paclitaxel in pharmaceutical forms without separation. Journal of pharmaceutical and biomedical analysis 2004; 34(3): 501-507.

17. Sadeghi-Aliabadi $H$. Solvent optimization on Taxol extraction from Taxus baccata $L$, using HPLC and $L C$ MS. Daru Journal of Pharmaceutical Sciences 2009; 17(3): 192-198.

18. Goyal N. Simultaneous determination of dexamethasone, dexamethasone 21 -acetate, and paclitaxel in a simulated biological matrix by RP-HPLC Assay development and validation. Journal of Liquid Chromatography \& Related Technologies 2008; 31(10): 1478-1491.

19. Hempel G. Determination of paclitaxel in biological fluids by micellar electrokinetic chromatography. Journal of Chromatography A 1996; 745(1-2): 173-179.

20. Leu JG. Characterization of polyclonal and monoclonal anti-taxol antibodies and measurement of taxol in serum. Cancer research 1993; 53(6): 1388-1391.

21. Rodriguez J. Determination of morphine, codeine, and paclitaxel in human serum and plasma by micellar electrokinetic chromatography. Journal of separation science 2012; 35(17): 2297-2306.

22. Morais S. A tubulin-based fluorescent polarization assay for paclitaxel. Analytical biochemistry 2003; 321(1): 4449.

Trop J Pharm Res, September 2021; 20(9): 1958 
23. Epshtein N. Validation of HPLC techniques for pharmaceutical analysis. Pharmaceutical Chemistry Journal 2004; 38(4): 212-228.

24. Khan A. An optimized and validated RP-HPLC/UV detection method for simultaneous determination of alltrans-Retinol (Vitamin A) and $\alpha$-Tocopherol (Vitamin E) in human serum, Comparison of different particulate reversed-phase HPLC columns. Journal of Chromatography B 2010; 878(25): 2339-2347.
25. Kim SC Sensitive HPLC method for quantitation of paclitaxel (Genexol囚) in biological samples with application to preclinical pharmacokinetics and biodistribution. Journal of pharmaceutical and biomedical analysis 2005; 39(1-2): 170-176.

26. Siddiqui S. RP-HPLC Method for Estimation and Stress Degradation Study of Paclitaxel as per ICH Guidelines. J. Chromatogr Sep Tech 2012; 2: 3-4. 